\title{
Heterologous expression of Phanerochaete chrysosporium cellobiose dehydrogenase in Trichoderma reesei
}

\author{
Lena Wohlschlager ${ }^{1}$, Florian Csarman ${ }^{1}$, Hucheng Chang ${ }^{1}$, Elisabeth Fitz² ${ }^{2}$ Bernhard Seiboth ${ }^{2}$ \\ and Roland Ludwig ${ }^{1 *}$ (D)
}

\begin{abstract}
Background: Cellobiose dehydrogenase from Phanerochaete chrysosporium $(P C C D H)$ is a key enzyme in lignocellulose depolymerization, biosensors and biofuel cells. For these applications, it should retain important molecular and catalytic properties when recombinantly expressed. While homologous expression is time-consuming and the prokaryote Escherichia coli is not suitable for expression of the two-domain flavocytochrome, the yeast Pichia pastoris is hyperglycosylating the enzyme. Fungal expression hosts like Aspergillus niger and Trichoderma reesei were successfully used to express CDH from the ascomycete Corynascus thermophilus. This study describes the expression of basidiomycetes $P C C D H$ in T. reesei $\left(P_{C} C D H_{T r}\right)$ and the detailed comparison of its molecular, catalytic and electrochemical properties in comparison with PCCDH expressed by P. chrysosporium and P. pastoris $\left(P_{C} C D H_{P p}\right)$.
\end{abstract}

Results: $P C C_{C D H}$ was recombinantly produced with a yield of $600 \mathrm{UL}^{-1}$ after 4 days, which is fast compared to the secretion of the enzyme by $P$. chrysosporium. $P_{C} C_{T} H_{T r}$ and $P C C D H$ were purified to homogeneity by two chromatographic steps. Both enzymes were comparatively characterized in terms of molecular and catalytic properties. The $\mathrm{pH}$ optima for electron acceptors are identical for $P_{C} C D H_{T r}$ and $P C C D H$. The determined FAD cofactor occupancy of $70 \%$ for $P C C D H_{T r}$ is higher than for other recombinantly produced $C D H s$ and its catalytic constants are in good accordance with those of $\mathrm{PCCDH}$. Mass spectrometry showed high mannose-type $\mathrm{N}$-glycans on $\mathrm{PCCDH}$, but only single $\mathrm{N}$-acetylD-glucosamine additions at the six potential N-glycosylation sites of $P C C_{C D H}$, which indicates the presence of an endo-N-acetyl- $\beta$-D-glucosaminidase in the supernatant.

Conclusions: Heterologous production of $\mathrm{PCCDH}_{T r}$ is faster and the yield higher than secretion by $P$. chrysosporium. It also does not need a cellulose-based medium that impedes efficient production and purification of CDH by binding to the polysaccharide. The obtained high uniformity of $P C C D H_{T r}$ glycoforms will be very useful to investigate electron transfer characteristics in biosensors and biofuel cells, which are depending on the spatial restrictions inflicted by high-mannose $\mathrm{N}$-glycan trees. The determined catalytic and electrochemical properties of $P C C D H_{T r}$ are very similar to those of PCCDH and the FAD cofactor occupancy is good, which advocates T. reesei as expression host for engineered PCCDH for biosensors and biofuel cells.

\footnotetext{
${ }^{*}$ Correspondence: roland.ludwig@boku.ac.at

${ }^{1}$ Biocatalysis and Biosensing Laboratory, Department of Food Science

and Technology, BOKU-University of Natural Resources and Life Sciences,

Muthgasse 18, 1190 Vienna, Austria

Full list of author information is available at the end of the article
}

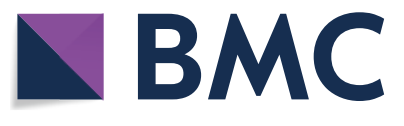

(c) The Author(s) 2021. This article is licensed under a Creative Commons Attribution 4.0 International License, which permits use, sharing, adaptation, distribution and reproduction in any medium or format, as long as you give appropriate credit to the original author(s) and the source, provide a link to the Creative Commons licence, and indicate if changes were made. The images or other third party material in this article are included in the article's Creative Commons licence, unless indicated otherwise in a credit line to the material. If material is not included in the article's Creative Commons licence and your intended use is not permitted by statutory regulation or exceeds the permitted use, you will need to obtain permission directly from the copyright holder. To view a copy of this licence, visit http://creativecommons.org/licenses/by/4.0/. The Creative Commons Public Domain Dedication waiver (http://creativecommons.org/publicdomain/zero/1.0/) applies to the data made available in this article, unless otherwise stated in a credit line to the data. 
Keywords: Cellobiose dehydrogenase, Catalytic constants, Cofactor occupancy, Glycosylation, Lignocellulose depolymerization, Phanerochaete chrysosporium, Redox potential, Trichoderma reesei

\section{Background}

In the gradual but sustained transition from crude oil towards renewable resources for energy, base- and fine chemicals, and materials, lignocellulosic biomass plays a key role. However, its recalcitrant nature makes the depolymerization and fractionation a challenging process $[1,2]$. The application of cellulolytic and ligninolytic fungal enzymes in a concerted manner to achieve controlled lignocellulose depolymerization and separation in e.g. biorefineries, is a promising strategy [3]. The rising of lytic polysaccharide monooxygenase (LPMO) as a major polysaccharide depolymerizing enzyme in fungal secretomes with a high applicability in biomass conversion has also raised the interest into its electron donor cellobiose dehydrogenase (CDH, EC1.1.99.18, CAZy: AA3.1) [4]. The first CDH was identified in the supernatant of white-rot fungus Phanerochaete chrysosporium $(P c \mathrm{CDH})$ and was considered to be an oxidase by Westermark and Eriksson in 1974 [5]. Bao et al. later found that this enzyme prefers electron acceptors like cytochrome $c$ and DCIP [6]. CDH is a two-domain enzyme consisting of a carbohydrate oxidizing dehydrogenase domain containing a FAD cofactor, which is linked to a heme $b$-containing cytochrome domain serving as an electron shuttle. The enzyme oxidizes cellulose and some hemicellulose degradation products (cellobiose, cello-oligosaccharides, xylo-oligosaccharides, and glucose) to the corresponding lactones thereby taking up electrons [7]. The exact function of $\mathrm{CDH}$ was unclear for decades [8, 9] until the discovery of LPMO in 2010 [10]. CDH's auxiliary function as an electron donor and a possible supplier of hydrogen peroxide to LPMO has been suggested by recent publications $[11,12]$.

Despite the previous uncertainty on its physiological role, $\mathrm{CDH}$ was considered an important enzyme for lactose oxidation, glucose biosensing and biofuel cells [13]. Until 2000, PcCDH was only available by isolating the native enzyme from its fungal producer [14, 15] which does not secrete the enzyme in large quantities (e.g. $66 \mathrm{U} \mathrm{L}^{-1}$ [6]). For the production of the enzyme in higher quantities and to be able to perform site-directed mutagenesis for mechanistic studies, a recombinant expression system for $\mathrm{CDH}$ is necessary. $\mathrm{Li}$ et al. presented the first homologous overexpression of $P c \mathrm{CDH}$ in P. chrysosporium, reaching $600 \mathrm{U} \mathrm{L}^{-1}$ after 9 days in stationary cultures [16]. A three-step purification resulted in a recombinant $P c C D H$ with a $\mathrm{RZ}$-value $\left(\mathrm{A}_{420} / \mathrm{A}_{480}\right)$ of approximately 0.55 and a specific activity of $8 \mathrm{U} \mathrm{mg}^{-1}$, while for isolated native $P c \mathrm{CDH}$ a $\mathrm{RZ}$ of 0.6 [15] and a higher specific activity of $10.3 \mathrm{U} \mathrm{mg}^{-1}$ [6] was reported. Shortly after this work, Yoshida et al. reported the heterologous expression of $\mathrm{PcCDH}$ in the yeast Pichia pastoris $\left(P_{c} \mathrm{CDH}_{P p}\right)$ in 2001 [17]. After 4 days of cultivation, the expressed enzyme exhibited a volumetric activity of $1800 \mathrm{U} \mathrm{L}^{-1}$. P. pastoris produces a high cell density in a short time span and carries the eukaryotic machinery for the posttranslational processing of proteins. On the downside, it is known for extensive hyperglycosylation [18], which can alter CDH's intramolecular electron transfer between the dehydrogenase and cytochrome domain. In contrast, the prokaryotic expression host Escherichia coli would not introduce $\mathrm{O}$ - and $\mathrm{N}$-glycans, but successful production of $\mathrm{CDH}$ has not been accomplished so far. Only expression of the sole dehydrogenase domain was achieved in E. coli $[19,20]$. Recombinant production of ascomycetes Corynascus thermophilus $\mathrm{CDH}$ in T. reesei and Aspergillus niger [20] indicated that fungal expression hosts could result in a decreased and more uniform glycosylation of recombinant $\mathrm{CDH}$. Trichoderma reesei is a well-established host for recombinant protein expression and does not produce a native $\mathrm{CDH}$ [21] making it a suitable organism for recombinant $\mathrm{CDH}$ production. In 2016, Wang and Lu reported the expression of the $c d h$ gene from $P$. chrysosporium in $T$. reesei to study the synergy between $\mathrm{CDH}$ and cellulases in vivo, however no yield, purification or characterization of the enzyme was described [22]. In this study, we expressed, purified and characterized $P c \mathrm{CDH}_{T r}$ and compared the obtained molecular, kinetic and electrochemical data to native $P c \mathrm{CDH}$ and $P_{c} \mathrm{CDH}_{P p}$.

\section{Results and discussion}

\section{Production and purification of $P C C D H$}

For heterologous expression of $P c \mathrm{CDH}_{T r}$ in $T$. ree$s e i$, the cDNA was cloned into the expression vector pLH_hph_nat (Additional file 1: Figure S1). The plasmid contains the strong cDNA1 promoter native to T. reesei and the hygromycin B phosphotransferase ( $h p h$ ) expression cassette as fungal selection marker. Additionally, it carries the ori region and the ampicillin resistance cassette for cloning in E. coli [23]. The expression construct was transformed into $T$. reesei strain $\Delta x y r 1$, a derivative from T. reesei QM9414 (ATCC 26,921) with deletion of the xylanase regulator $1(\Delta x y r 1)$. Xyr 1 has been shown to be a major cellulase and xylanase regulator [24] and its removal provides a (hemi)cellulase-reduced background 
advantageous for protein production [23]. Spore electroporation was chosen as transformation method since this technique has been described as a less time consuming and easier to handle technique than protoplast transformation [25]. Most filamentous fungi like T. reesei follow the non-homologous end joining pathway for DNA repair and gene integration over homologous directed recombination [26, 27] resulting in a random integration of the target gene.

We verified the presence of the gene encoding for $P c C D H$ in the genomic DNA by colony PCR for the obtained transformants, which were resistant to the selection marker hygromycin $B$. The gene was integrated in nine out of nine tested transformants, however, we soon discovered that positive retracing of the gene did not ensure the successful expression of the enzyme. We therefore turned to screening for mitotic stability and protein expression. The first was achieved by growing the transformants on PDA plates without selection pressure for 2 days, followed by transferring a piece of young mycelium back to PDA plates containing hygromycin B. Transformants that maintained their growth were considered to have the plasmid stably integrated into their genome. Screening for protein expression was performed in smallscale shake flasks experiments including one flask with untransformed T. reesei strain $\Delta x y r 1$ as negative control that exhibited no cytochrome $c$ activity in the screening. From two transformants that showed $\mathrm{CDH}$ activity with the cytochrome $c$ assay after 7 days of cultivation the better one was used for protein production in 1-L Erlenmeyer flasks filled with $200 \mathrm{~mL}$ of MA-medium. On day 4 , the average cytochrome $c$ activity measured in the 8 expression flasks was $700 \pm 10 \mathrm{U} \mathrm{L}^{-1}$. Since no increase was observed on day 5 , the cultures were harvested and pooled for purification. In the pooled, clear supernatant, a volumetric activity of $610 \pm 2 \mathrm{U} \mathrm{L}^{-1}$ was determined. $\mathrm{Li}$ et al. obtained a similar activity $\left(600 \mathrm{U} \mathrm{L}^{-1}\right)$ in their homologous overexpression of mutated $P c \mathrm{CDH}$, however only after 9 days [16]. Production of $P c \mathrm{CDH}_{P p}$ in P. pastoris by Yoshida et al. resulted in a higher volumetric activity of $1800 \mathrm{U} \mathrm{L}^{-1}$ after 4 days of cultivation [17].

A two-step purification protocol (Table 1) consisting of hydrophobic interaction chromatography followed by anion exchange chromatography resulted in a homogeneously purified protein as judged by SDS-PAGE. The total amount of pure $P c \mathrm{CDH}_{T r}$ obtained from eight shaking flasks was $58 \mathrm{mg}$ (determined via absorbance at $280 \mathrm{~nm}$ ) with a specific activity of $12.7 \mathrm{U} \mathrm{mg}^{-1}$.

\section{Molecular properties and MS analysis}

The high measured RZ-value $\left(\mathrm{A}_{420} / \mathrm{A}_{280}\right)$ of 0.62 is in accordance with published data of native $P c \mathrm{CDH}$ (>0.6, [15]) as well as recombinant $P_{c} \mathrm{CDH}_{P p}(0.61$, [17]), which verifies the purity of the prepared $P c C D$ $\mathrm{H}_{T r}$ and additionally indicates a high occupancy of the heme $b$ cofactor in the cytochrome domain. The SDSPAGE gives a molar mass of $83,000 \mathrm{~g} \mathrm{~mol}^{-1}$ of $P c \mathrm{CDH}_{T r}$ (Fig. 1, lane 1). That is around $4000 \mathrm{~g} \mathrm{~mol}^{-1}$ lower than the molar mass of $P c \mathrm{CDH}$ with $87,000 \mathrm{~g} \mathrm{~mol}^{-1}$ (Fig. 1, lane 3). The calculated molar mass based on the mature amino acid sequence and the mass of both cofactors is $81550 \mathrm{~g} \mathrm{~mol}^{-1}$. The published molar mass of $P c \mathrm{CDH}$ is $90000 \mathrm{~g} \mathrm{~mol}^{-1}$ according to SDS-PAGE analysis $[6,14]$. $P c \mathrm{CDH}_{P p}$ shows a higher molar mass of $100,000 \mathrm{~g} \mathrm{~mol}^{-1}$, which has been correlated to hyperglycosylation frequently observed for proteins overexpressed in P. pastoris $[17,28,29]$.

Samples of $P c \mathrm{CDH}_{T r}$ and $P c \mathrm{CDH}$ were subjected to proteolytic digestion and ESI-MS analysis to determine the $\mathrm{N}$-glycosylation on the six NXS/NXT sequons identified as potential glycosylation sites in the mature amino acid sequence of $P c \mathrm{CDH}$ (Additional file 1: Figure S2). $P c \mathrm{CDH}$ shows high mannose-type $\mathrm{N}$-glycans, which was verified for four positions of the isolated enzyme (Additional

Table 1 Purification scheme of recombinantly produced $\mathrm{PCCDH}_{T r}$

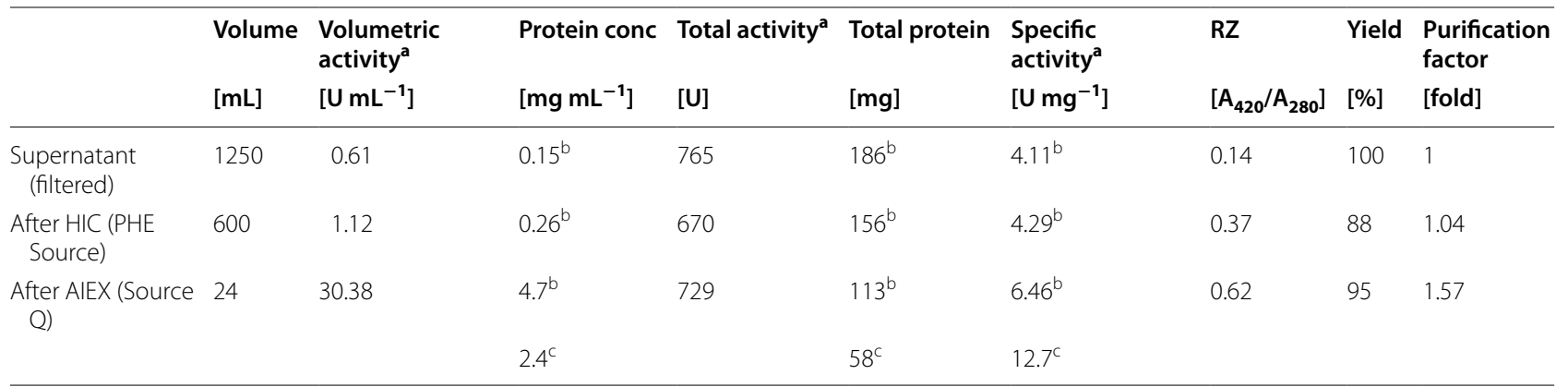

\footnotetext{
activity measured with lactose and cytochrome $\mathrm{c}$ at $\mathrm{pH} 4.5$

b Protein concentration measured with Bradford assay

c Protein concentration determined via the absorbance at $280 \mathrm{~nm}$ and $\varepsilon_{280}=156,400 \mathrm{M}^{-1} \mathrm{~cm}^{-1}$
} 


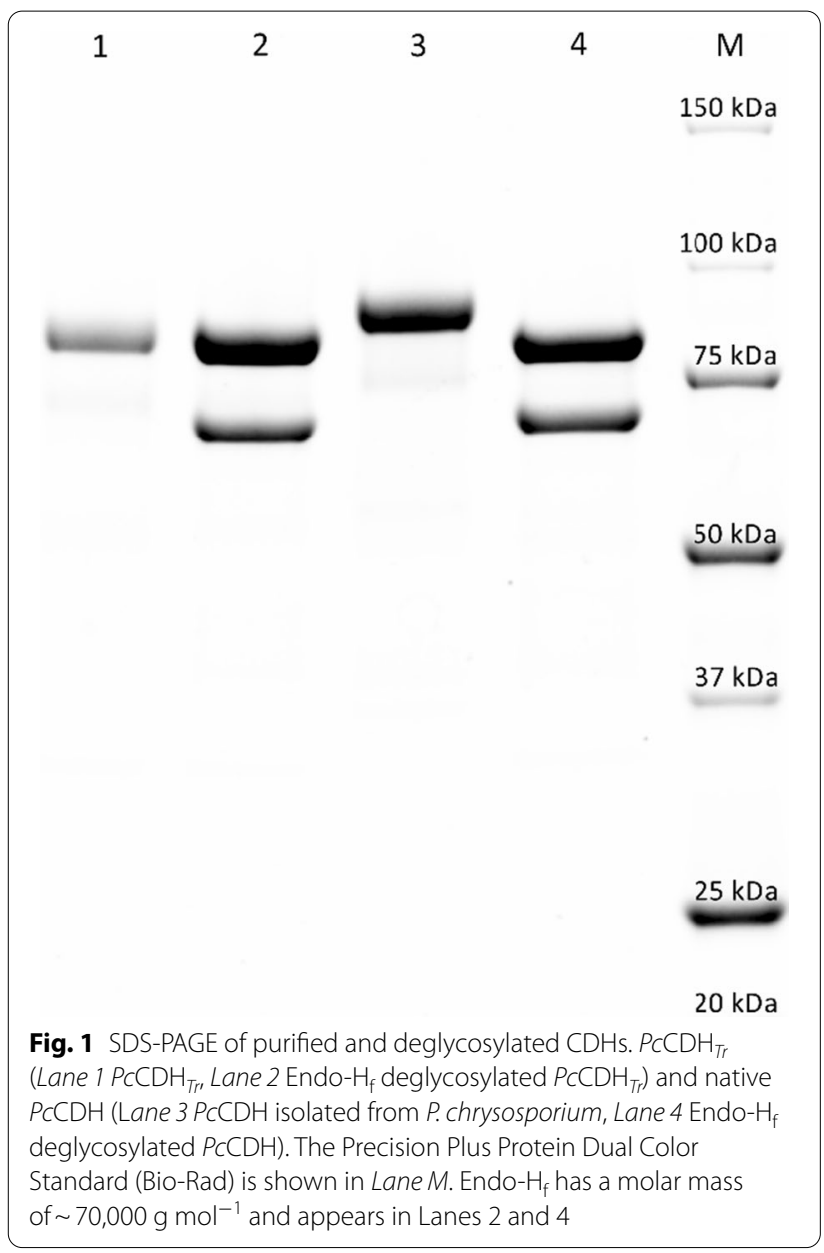

file 1: Figures $\mathrm{S} 3-\mathrm{S} 6)$. Recombinant $P c \mathrm{CDH}_{T r}$ only shows the presence of single $\mathrm{N}$-acetyl-D-glucosamine (GlcNAc) residues at all six potential glycosylation sites (Additional file 1: Figures S3-S7). These findings coincide with the SDS-PAGE analysis (Fig. 1). The detection of single GlcNAc residues points towards the deglycosylation of the protein-bound high-mannose $N$-glycans. This phenomenon has also been observed for secreted enzymes native to T. reesei [30-32]. The three cited articles found that different enzyme production methods (e.g. smallscale shake flasks vs. aerated fermentation) and varying cultivation parameters influence the glycan structures on T. reesei cellulases [30]. For example, expression at $\mathrm{pH} 4$ produced Man8 glycans on the cellobiohydrolase I from $T$. reesei while cultivation at $\mathrm{pH} 5$ resulted in cellobioshydrolase I with only GlcNAc residues [31]. These observations were connected to the presence of endo-Nacetyl- $\beta$-D-glucosaminidase activity in the supernatant which was later confirmed by Stals et al. who found and characterized the enzyme Endo T [33, 34].

\section{Spectroscopic analysis (UV/Vis and FAD loading)}

The UV/Vis spectrum obtained for the purified $P c C D$ $\mathrm{H}_{T r}$ resembles that of a typical flavocytochrome (Fig. 2a, red dashed line). The dominant Soret-band of the heme $b$ cofactor appears at $420 \mathrm{~nm}$. It veils the absorbance of the FAD cofactor, which shows maxima at 375 and $450 \mathrm{~nm}$ in its isolated form (Fig. 2b). In the spectrum of the flavocytochrome the presence of the FAD can only be observed in the region between $430-500 \mathrm{~nm}$ between the Soret-band and the heme $b \beta$-peak. Upon reduction, the Soret-band shifts to $429 \mathrm{~nm}$, and the $\beta$ - and $\alpha$-peaks of the reduced heme appear at 532 and $563 \mathrm{~nm}$, respectively (Fig. 2a, blue solid line). The recorded spectra of $P c C D$ $\mathrm{H}_{T r}$ show all the characteristics typical for published spectra of native $P c \mathrm{CDH}[6]$.
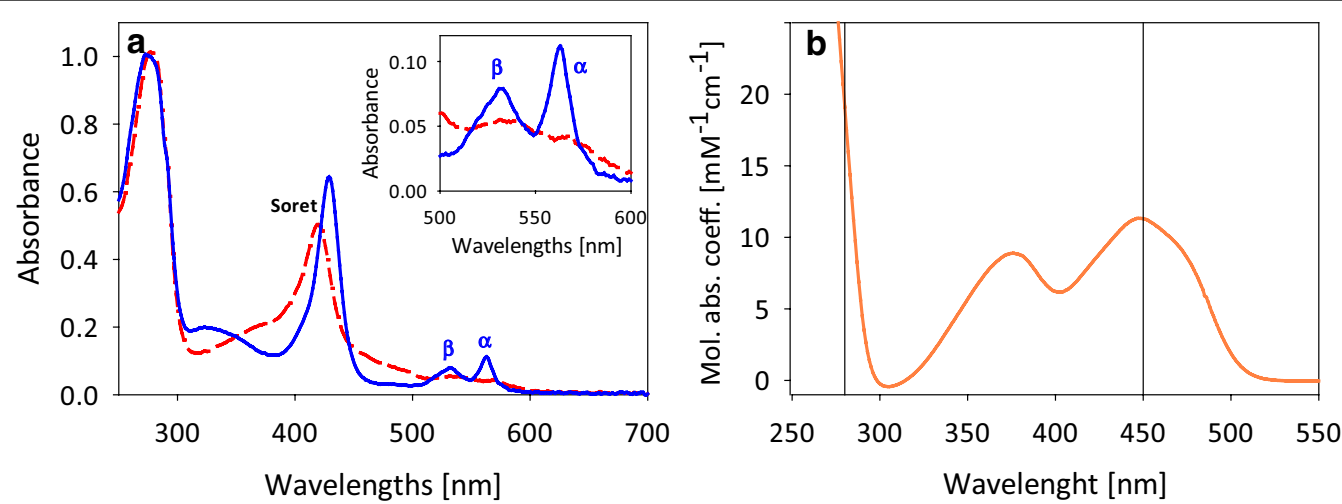

Fig. 2 Spectral analysis. a UVNis spectra of oxidized (red, dashed line) and reduced (blue, solid line) $P_{C C D H}$ (70 $\mu M$ ). For obtaining the reduced spectrum, $1 \mathrm{mM}$ cellobiose was added to the purified enzyme solution in $50 \mathrm{mM}$ sodium acetate buffer, pH 4. Inset: Magnification of the spectrum between 500 and $600 \mathrm{~nm}$ to show the heme $b$ a- and $\beta$-peak in more detail. $\mathbf{b}$ UVNis spectrum of the supernatant after trichloroacetic acid precipitation of $\mathrm{PCCDH}_{T r}$ for determining the FAD occupancy. The wavelengths 280 and $450 \mathrm{~nm}$ are marked with vertical lines and show the contribution of the FAD cofactor to the molar absorption coefficient at $280 \mathrm{~nm}$ used for the calculation of the protein concentration 
For the determination of the FAD loading, a sample of $P c \mathrm{CDH}_{T r}$ was subjected to trichloroacetic acid treatment, which resulted in the release of the FAD to the supernatant while precipitating the protein with the heme cofactor. The amount of FAD was calculated from the absorbance at $450 \mathrm{~nm}$ in the clarified supernatant, while the protein concentration was determined from the $\mathrm{A}_{280}$ value. However, since FAD also absorbs at $280 \mathrm{~nm}$ (Fig. 2b) to a non-neglectable extent, its contribution to the $\mathrm{A}_{280}$ value was considered. For the initial calculation of protein concentration, $100 \%$ FAD loading was assumed and a molar absorption coefficient of $\varepsilon_{280}=162.6 \mathrm{mM}^{-1} \mathrm{~cm}^{-1}$ was used (sum of $\varepsilon_{280}=142 \mathrm{mM}^{-1} \mathrm{~cm}^{-1}$ for $P c \mathrm{CDH}_{T r}$ (see Materials and Methods) and $\varepsilon_{280}=20.6 \mathrm{mM}^{-1} \mathrm{~cm}^{-1}$ for free FAD [35]). The resulting FAD occupancy was applied to adapt the percentage of FAD contributing to the overall absorption coefficient at $280 \mathrm{~nm}$. An iterative calculation resulted in a FAD loading of $70 \%$ and a molar absorption coefficient for recombinant $P c \mathrm{CDH}_{T r}$ of $156.4 \mathrm{mM}^{-1} \mathrm{~cm}^{-1}$.

This result is similar to the FAD occupancy published for $T$. reesei-produced $\mathrm{CDH}$ from $C$. thermophilus $(\mathrm{CtCDH})$ [20]. In contrast, $\mathrm{CtCDH}$ expressed in $P$. pastoris contained only $30 \%$ FAD in the active site, whereas for native $\mathrm{CtCDH} 92 \%$ occupancy were reported [36]. For native and homologously expressed $\mathrm{CDH}$ from $P$. chrysosporium ratios of protein to FAD of $1: 1$ were reported $[6,16]$.

\section{Comparison of specific activities, pH optima and catalytic constants}

$\mathrm{PcCDH}_{T r}$ has a $\mathrm{pH}$ optimum for the one-electron acceptor cytochrome $c$ between 3.5 and 4.0 (Fig. 3a, red dots). For the two-electron acceptor 2,6-dichloroindophenol (DCIP) the $\mathrm{pH}$ optimum is found at $\mathrm{pH} 4.5$ (Fig. 3b, red dots). These results are in accordance with the values measured for $\mathrm{PcCDH}$ (Fig. 3a, b, blue squares) as well as the published $\mathrm{pH}$ optimum for cytochrome $c(\mathrm{pH} 3.5-$ 4.0) determined by Igarashi et al. for $P c C D H$ [14]. The varying $\mathrm{pH}$ optima of $\mathrm{CDH}$ for different electron acceptors depends on their reduction mechanism. Whereas DCIP is directly reduced at the $\mathrm{FADH}_{2}$, the reduction of cytochrome $c$ by the heme $b$ cofactor depends also on an interdomain electron transfer step between the flavodehydrogenase and the cytochrome domain of $\mathrm{CDH}$, which is also $\mathrm{pH}$ dependent. The specific activities of $\mathrm{PCCDH}_{T r}$ for cytochrome $c$ and DCIP with cellobiose as substrate were $10.8 \mathrm{U} \mathrm{mg}^{-1}$ and $17.5 \mathrm{U} \mathrm{mg}^{-1}$ at their optimum $\mathrm{pH}$, respectively (Table 2). For the native $\mathrm{PcCDH}$, the specific activities were 12.9 and $18.3 \mathrm{U} \mathrm{mg}^{-1}$, respectively, which can be explained by a higher FAD occupancy. The specific activity is also in accordance with the specific activity published for $\mathrm{PcCDH}$ by Bao et al. (10.3 $\mathrm{U} \mathrm{mg}^{-1}$ ) when considering the different buffer, $\mathrm{pH}$, substrate and electron acceptor concentration [6]. At the respective optimum $\mathrm{pH}$ of the electron acceptor, the specific activities were also determined for the electron donor lactose (Table 2).

Steady-state kinetic measurements were performed at the $\mathrm{pH}$ optimum of the electron acceptor. The determined $K_{\mathrm{M}}$ and $k_{\text {cat }}$ values (Table 3) of $\mathrm{PcCDH}_{T r}$ for the

Table 2 Comparison of specific activities of $\mathrm{PCCDH}_{T r}$ and $P C C D H$

\begin{tabular}{llllll}
\hline & \multicolumn{2}{l}{$\mathrm{PcCDH}_{\text {Tr }}\left[\mathrm{U} \mathrm{mg}^{-\mathbf{1}}\right]$} & & \multicolumn{2}{l}{$\boldsymbol{P c C D H}\left[\mathrm{U} \mathrm{mg}^{-\mathbf{1}}\right]$} \\
\cline { 2 - 3 } & Cellobiose & Lactose & & Cellobiose & Lactose \\
\hline Cytochrome C & $10.8 \pm 0.7$ & $15.1 \pm 0.3$ & & $12.9 \pm 0.1$ & $16.0 \pm 0.8$ \\
DCIP & $17.5 \pm 0.3$ & $23.4 \pm 1.0$ & & $18.3 \pm 0.6$ & $23.8 \pm 1.4$ \\
\hline
\end{tabular}
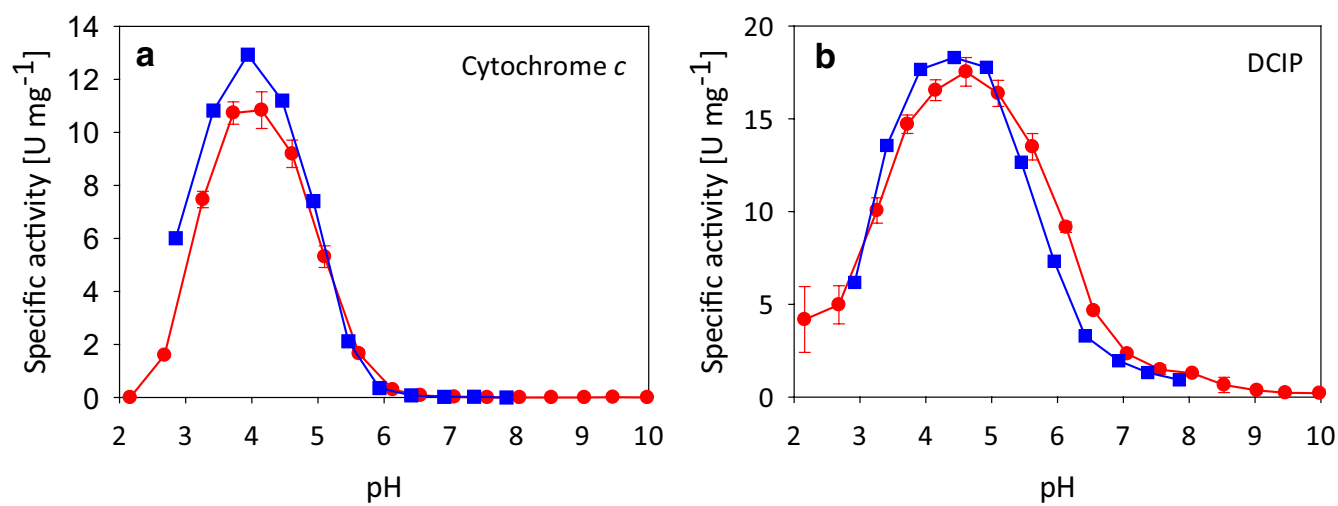

Fig. 3 pH Optima. pH Profiles of PCCDH (blue squares) and $P C C D H$ (red dots) with the two electron acceptors cytochrome $c$ (a) and DCIP (b). Measurements of recombinant $P C C_{T r}$ were done in triplicate. Bars represent standard deviation of the mean. Due to lack of isolated enzyme, measurements of native PCCDH were performed only in duplicate. The deviation of the replicates was in all cases below 5\% 


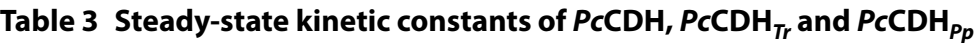

\begin{tabular}{|c|c|c|c|c|c|c|c|c|c|c|c|}
\hline \multirow[t]{2}{*}{ Electron donors } & \multicolumn{3}{|l|}{ This study: $P c C D D H_{T r}{ }^{a}$} & \multicolumn{4}{|c|}{ Published: PcCDH } & \multicolumn{4}{|c|}{ Published: $P c C \mathrm{H}_{P p}$} \\
\hline & $\begin{array}{l}K_{\mathrm{M}}^{\mathrm{b}} \\
{[\mathrm{mM}]}\end{array}$ & $\begin{array}{l}k_{\text {cat }}^{\mathbf{b}} \\
{\left[\mathrm{s}^{-1}\right]}\end{array}$ & $\begin{array}{l}k_{\mathrm{cat}} / K_{\mathrm{M}}^{\mathrm{b}} \\
{\left[\mathrm{mM}^{-1} \mathrm{~s}^{-1}\right]}\end{array}$ & $\begin{array}{l}K_{\mathrm{M}} \\
{[\mathrm{mM}]}\end{array}$ & $\begin{array}{l}k_{\text {cat }} \\
{\left[\mathrm{s}^{-1}\right]}\end{array}$ & $\begin{array}{l}k_{\mathrm{cat}} / K_{\mathrm{M}} \\
{\left[\mathrm{mM}^{-1} \mathrm{~s}^{-1}\right]}\end{array}$ & Refs. & $\begin{array}{l}K_{\mathrm{M}} \\
{[\mathrm{mM}]}\end{array}$ & $\begin{array}{l}k_{\mathrm{cat}} \\
{\left[\mathrm{s}^{-1}\right]}\end{array}$ & $\begin{array}{l}k_{\mathrm{cat}} / K_{\mathrm{M}} \\
{\left[\mathrm{mM}^{-1} \mathrm{~s}^{-1}\right]}\end{array}$ & Refs. \\
\hline \multirow[t]{2}{*}{ Cellobiose } & $0.08 \pm 0.008$ & $27.8 \pm 0.9$ & $340 \pm 35$ & 0.04 & 25.7 & 643 & {$[32]$} & $0.06^{\mathrm{e}}$ & $40^{\mathrm{e}}$ & $689^{e}$ & {$[16]$} \\
\hline & & & & 0.11 & 15.7 & 143 & [14] & 0.06 & $3.6^{f}$ & $60.3^{f}$ & {$[24]$} \\
\hline Lactose & $1.42 \pm 0.08$ & $32.3 \pm 1.9$ & $22.7 \pm 1.8$ & 1.1 & 13.4 & 12 & [14] & 1.16 & $4.7^{f}$ & $4.1^{f}$ & {$[24]$} \\
\hline Glucose & $2109 \pm 171$ & $7.8 \pm 0.5$ & $0.004 \pm 0.0004$ & 1600 & 2.64 & 0.0017 & [14] & & & & \\
\hline Electron acceptors & $\begin{array}{l}K_{\mathrm{M}} \\
{[\mathrm{mM}]}\end{array}$ & $\begin{array}{l}k_{\text {cat }} \\
{\left[\mathrm{s}^{-1}\right]}\end{array}$ & $\begin{array}{l}k_{\mathrm{cat}} / K_{\mathrm{M}} \\
{\left[\mathrm{mM}^{-1} \mathrm{~s}^{-1}\right]}\end{array}$ & $\begin{array}{l}K_{\mathrm{M}} \\
{[\mathrm{mM}]}\end{array}$ & $\begin{array}{l}k_{\text {cat }} \\
{\left[\mathrm{s}^{-1}\right]}\end{array}$ & $\begin{array}{l}k_{\mathrm{cat}} / K_{\mathrm{M}} \\
{\left[\mathrm{mM}^{-1} \mathrm{~s}^{-1}\right]}\end{array}$ & Refs. & $\begin{array}{l}K_{\mathrm{M}} \\
{[\mathrm{mM}]}\end{array}$ & $\begin{array}{l}k_{\text {cat }} \\
{\left[s^{-1}\right]}\end{array}$ & $\begin{array}{l}k_{\mathrm{cat}} / K_{\mathrm{M}} \\
{\left[\mathrm{mM}^{-1} \mathrm{~s}^{-1}\right]}\end{array}$ & Refs. \\
\hline \multirow[t]{2}{*}{ Cytochrome c } & $0.00036 \pm 0.00009^{c}$ & $13.0 \pm 0.2^{c}$ & $36,143 \pm 8618^{c}$ & 0.001 & 20.5 & 17,083 & {$[6]$} & 0.001 & 37.3 & 25,903 & {$[16]$} \\
\hline & & & & 0.0007 & 14.2 & 20,286 & [32] & & & & \\
\hline \multirow[t]{2}{*}{ DCIP } & $0.00431 \pm 0.00011^{d}$ & $24.4 \pm 0.2^{d}$ & $5655 \pm 159^{d}$ & 0.004 & 33 & 9167 & [6] & & & & \\
\hline & & & & 0.006 & 27 & 4219 & {$[32]$} & & & & \\
\hline
\end{tabular}

a Measurements were done in triplicates

b Measured with $300 \mu \mathrm{M} \mathrm{DCIP}$ at $\mathrm{pH} 4.5$

c Measured with $500 \mu \mathrm{M}$ cellobiose at $\mathrm{pH} 4.0$

$d$ Measured with $500 \mu \mathrm{M}$ cellobiose at $\mathrm{pH} 4.5$

e Ubiquinone used as electron acceptor

${ }^{f}$ Values calculated from $V_{\max }$ given in reference [28]

natural substrate cellobiose are comparable to the catalytic constants published for $P c C D H$ published by Rotsaert et al. [37]. Yoshida et al. also reports similar catalytic constants for $P c \mathrm{CDH}_{P p}$ [17]. However, for the recombinant $P c \mathrm{CDH}$ dehydrogenase domain produced in $P$. pastoris by Desriani et al. a ten times lower $k_{\text {cat }}\left(3.6 \mathrm{~s}^{-1}\right)$ has been reported [28], which indicates either a low purity of the enzyme preparation of a low cofactor occupancy. The catalytic constants of $P_{c} \mathrm{CDH}_{T r}$ for the electron acceptors cytochrome $c$ and DCIP are also comparable to the native PcCDH (Table 3).

Mono- and di-substituted quinones have been shown to be good electron acceptors of $\mathrm{CDH}$ and capable redox mediators in the electron transfer system between lytic polysaccharide monooxygenase (LPMO) and glucose dehydrogenase from Glomerella cingulata, as $\mathrm{CDH}$ a member of the glucose-methanol-choline oxidoreductase family $[38,39]$. To study LPMO-related redox mediators as electron acceptors of $P c \mathrm{CDH}_{T r}$ the $\mathrm{pH}$ optimum $\mathrm{pH}$ for unsubstituted 1,4-benzoquinone was determined (Fig. 4, insert). It shows the highest activity with $16.05 \mathrm{U}$ $\mathrm{mg}^{-1}$ at $\mathrm{pH} 4.0$, but also exhibits more than $50 \%$ activity in a broad $\mathrm{pH}$ range between $\mathrm{pH}$ 3.0-6.0. The reduction of the substituted quinones under investigation were therefore measured at $\mathrm{pH}$ 4.0. The results in Fig. 4 show that with increasing number of electron-donating groups at the quinone and with therefore decreasing redox potential, the reaction rates with $P c \mathrm{CDH}_{T r}$ decrease. This indicates that they are less suitable electron acceptors for

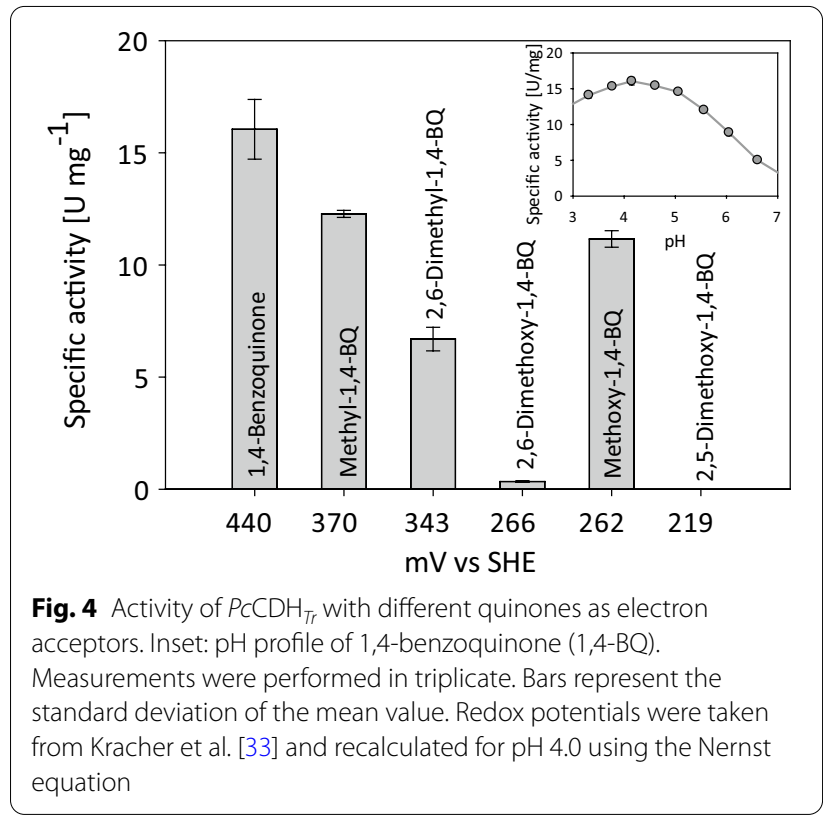

$\mathrm{CDH}$ although they are working well as redox mediators between glucose dehydrogenase and LPMO. When using the midpoint potential of FAD in $P c C D H$, which was determined by Igarashi et al. to be $106 \mathrm{mV}$ vs. SHE at $\mathrm{pH}$ 3.0 and $-132 \mathrm{mV}$ vs. SHE at $\mathrm{pH} 7.0$ [40] and the Nernst equation, the redox potential for $\mathrm{pH} 4.0$ can be calculated (165.5 mV vs. SHE). Comparing this value to the redox 
potentials of the quinones, it is apparent that all quinones have a higher redox potential than $\mathrm{CDH}$ and should be acting as electron acceptors. However, only some of the tested quinones were functional electron acceptors for $\mathrm{CDH}$ in this experimental setup. Therefore, we conclude that other factors, such as the steric access of the more bulky quinones to the catalytic site, have a strong ratelimiting effect.

\section{Redox properties of $P C \mathrm{CDH}_{T r}$}

The midpoint potential of the $P c \mathrm{CDH}_{T r}$ cytochrome heme- $b$ cofactor was determined by square-wave voltammetry. The obtained values range from $203 \mathrm{mV}$ vs. SHE at $\mathrm{pH} 3.2$ to $146 \mathrm{mV}$ vs. SHE at pH 5.3 (Fig. 5). This is in accordance with the redox potential published by Igarashi et al. for $P_{c} \mathrm{CDH}_{P p}$ (from $190 \mathrm{mV}$ vs. NHE at $\mathrm{pH} 3.0$ to $160 \mathrm{mV}$ vs. NHE at $\mathrm{pH} 5.0$, which were obtained by cyclic voltammetry [41]). These results demonstrate that $P c \mathrm{CDH}_{T r}$ has the same redox properties and can replace $P c \mathrm{CDH}_{P p}$ in biosensor and biofuel cell applications.

\section{Conclusions}

The recombinant production, purification and characterization of CDH from P. chrysosporium showed that $T$. ree$s e i$ is a suitable expression host for this flavocytochrome. The heterologous production was efficient by obtaining a high yield in a short cultivation time. The obtained $P C \mathrm{CDH}_{T r}$ preparation was pure and had a reasonably high heme $b$ and FAD occupancy in the cofactor-binding sites. Especially the lesser degree of glycosylation and the more uniform distribution resulting in less glycoforms make $P c \mathrm{CDH}_{T r}$ well suited for applications in which the

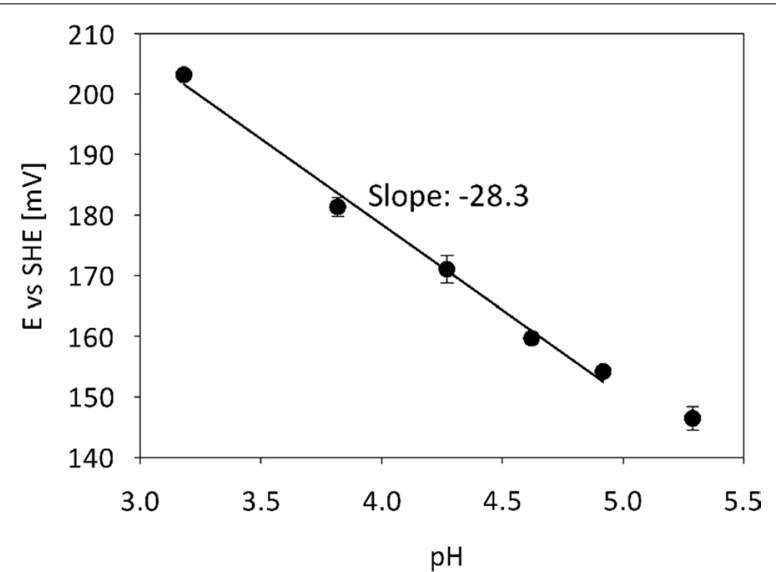

Fig. $5 \mathrm{pH}$-Dependence of the heme-domain redox potential of $P C C D H_{T r}$ obtained by squarewave voltammetry. Midpoint redox potentials were measured using a thioglycerol-modified gold electrode. $\mathrm{Ag} / \mathrm{AgCl}$ was used as reference electrode, but values were recalculated to SHE. Measurements were done in triplicate electron transfer between the domains and further to an electrode surface are required. It will also increase the efficiency and facilitate enzyme immobilization on electrode surfaces. Furthermore, the rediced glycosylation and higher homogeneity of $P c \mathrm{CDH}_{T r}$ will be useful for binding and interaction studies on natural substrates of $\mathrm{CDH}$. In terms of catalytic as well as electrochemical properties, $P c \mathrm{CDH}_{T r}$ performs in excellent resemblance to native $P c \mathrm{CDH}$. We therefore conclude that $T$. reesei is a suitable expression host for the production of native and engineered basidiomycetous CDHs.

\section{Materials and methods}

\section{Chemicals, vectors and genes}

All chemicals were purchased from Sigma-Aldrich (St. Louis, MO, USA), Carl Roth (Karlsruhe, DE) or VWR (Radnor, PA, USA) in the highest purity available. Reagents for molecular biological methods were obtained from New England Biolabs (NEB, Ipswich, MA, USA). The nucleotide sequence of $P c \mathrm{CDH}$ including its native signal peptide was obtained from GenBank (entry U46081.1) that contains the cDNA cloned from Phanerochaete chrysosporium strain OGC101 (a derivative of VKM-F-1767) [42]. The coding region of the cDNA flanked by a BclI restriction site on the $5^{\prime}$-end and NotI on the $3^{\prime}$-end for further cloning experiments, was synthesized by BioCat $\mathrm{GmbH}$ (Heidelberg, $\mathrm{DE}$ ) and provided in a pPICZ A plasmid. As expression vector, the plasmid pLH_hph_nat (Additional file 1: Figure S1) - a modified version of the plasmid pPcdnal [23] - was used for transforming and expressing Pccdh in T. reesei. Purified $\mathrm{H}_{2} \mathrm{O}$ $(>18 \mathrm{M} \Omega \mathrm{cm}$ ) was obtained from a SG system (Barsbüttel, GER) feeded with deionized water.

\section{Strains and media}

For vector construction and amplification, chemically competent $E$. coli strain NEB $5 \alpha$ and methyltransferasedeficient $\left(\mathrm{dam}^{-} / \mathrm{dcm}^{-}\right)$chemically competent $E$. coli cells were purchased from NEB. E. coli cultures were grown at $37{ }^{\circ} \mathrm{C}$ in liquid LB (lysogeny broth) medium or on agarcontaining LB plates supplemented with suitable selection marker (100 $\mu \mathrm{g} \mathrm{mL}^{-1}$ ampicillin, $25 \mu \mathrm{g} \mathrm{mL}^{-1}$ zeocin). Protein expression was carried out in $T$. reesei strain $\Delta x y r 1$ [24] that was grown on potato dextrose agar (PDA) plates. Selection and growth of transformants was maintained on PDA plates containing $50 \mu \mathrm{g} \mathrm{mL} \mathrm{m}^{-1}$ hygromycin B. Expression of $P c \mathrm{CDH}_{T r}$ was performed in modified Mandels-Andreotti (MA) medium containing $10 \mathrm{~g} \mathrm{~L}^{-1}$ glucose, $1.4 \mathrm{~g} \mathrm{~L}^{-1}\left(\mathrm{NH}_{4}\right)_{2} \mathrm{SO}_{4}, 4.0 \mathrm{~g} \mathrm{~L}^{-1} \mathrm{KH}_{2} \mathrm{PO}_{4}, 0.3 \mathrm{~g} \mathrm{~L}^{-1}$ urea, $0.3 \mathrm{~g} \mathrm{~L}^{-1} \mathrm{MgSO}_{4} \cdot 7 \mathrm{H}_{2} \mathrm{O}, 0.4 \mathrm{~g} \mathrm{~L}^{-1}, \mathrm{CaCl}_{2} \cdot 2 \mathrm{H}_{2} \mathrm{O}$, $1 \mathrm{~g} \mathrm{~L}^{-1}$ peptone, and $1 \%(\mathrm{v} / \mathrm{v})$ of trace element solution $\left(0.5 \mathrm{~g} \mathrm{~L}^{-1} \mathrm{FeSO}_{4} \cdot 7 \mathrm{H}_{2} \mathrm{O}, 0.16 \mathrm{~g} \mathrm{~L}^{-1} \mathrm{MnSO}_{4} \cdot \mathrm{H}_{2} \mathrm{O}\right.$, $\left.0.14 \mathrm{~g} \mathrm{~L}^{-1} \mathrm{ZnSO}_{4} \cdot 7 \mathrm{H}_{2} \mathrm{O}, 0.2 \mathrm{~g} \mathrm{~L}^{-1} \mathrm{CoCl}_{2} \cdot 2 \mathrm{H}_{2} \mathrm{O}\right)$, titrated 
to $\mathrm{pH} 6.0$ and inoculated with $10^{6}$ spores $\mathrm{mL}^{-1}$. The production of $P c \mathrm{CDH}$ by $P$. chrysosporium $\mathrm{K} 3$ (a kind gift of the late Prof. Jindřich Volc, Inst. of Microbiology, Czech Academy of Sciences) was done in a medium containing $30 \mathrm{~g} \mathrm{~L}^{-1} \alpha$-cellulose, $30 \mathrm{~g} \mathrm{~L}^{-1}$ yeast extract and $1 \mathrm{~g} \mathrm{~L}^{-1}$ $\mathrm{MgSO}_{4} \cdot 7 \mathrm{H}_{2} \mathrm{O}$ titrated with $\mathrm{H}_{3} \mathrm{PO}_{4}$ to $\mathrm{pH}$ 5.0.

\section{Construction of $T$. reesei expression vector}

The expression vector $\mathrm{pLH}$ h $p h h_{-}$nat was amplified in $E$. coli strain NEB $5 \alpha$, purified using the Monarch ${ }^{\circledR}$ Plasmid Miniprep Kit (NEB) and digested with restriction enzymes BglII and NotI from NEB according to their Double Digest Protocol. Plasmid pPICZ A carrying the gene encoding for $P c \mathrm{CDH}$ was amplified in methyltransferase-deficient $\left(\mathrm{dam}^{-} / \mathrm{dcm}^{-}\right)$chemically competent $E$. coli cells because the BclI restriction site on the $5^{\prime}$-terminus is blocked by methylated DNA. Purification of the plasmid was again performed with the Monarch ${ }^{\circledR}$ Plasmid Miniprep Kit and the gene cut from the pPICZ A vector backbone using restriction enzymes BclI and NotI. Since BclI and BglII create the same overhangs, the gene fragment could be ligated into pLH_hph_nat using T4 DNA ligase. Successful cloning was verified by agarose gel electrophoreses and DNA sequencing with primers 5pLHseq1 and 3pLHseq1 (Microsynth, Balgach, $\mathrm{CH}$ ). For transformation, the ligated plasmid was linearized with SbfI.

\section{Transformation into T. reesei $\Delta x y r 1$}

Trichoderma reesei transformation was done by spore electroporation according to a modified version of the protocol from [25]. T. reesei strain $\Delta x y r 1$ was cultivated on PDA plates for 7 days at $30{ }^{\circ} \mathrm{C}$ until the plate was fully sporulated. The spores were harvested with sterile, purified $\mathrm{H}_{2} \mathrm{O}$, filtered through glass-wool to remove mycelium and centrifuged at $3000 \times g$ for $3 \mathrm{~min}$ at $4{ }^{\circ} \mathrm{C}$. After removing the supernatant, the spores were washed with $1 \mathrm{M} 4{ }^{\circ} \mathrm{C}$-cold sorbitol solution twice and resuspended in $100 \mu \mathrm{L} 1 \mathrm{M}$ cold sorbitol solution to obtain a dark-green spore suspension. The linearized plasmid $(2.8 \mu \mathrm{g})$ was added to $100 \mu \mathrm{L}$ spore suspension and electroporation carried out in a $0.1-\mathrm{cm}$ electroporation cuvette with an applied voltage of $2.1 \mathrm{kV}$ (MicroPulser Electroporator, Bio-Rad). The spores were immediately resuspended in $1 \mathrm{~mL}$ CML (Complete Media Lactose) medium containing $5 \mathrm{~g} \mathrm{~L}^{-1}$ yeast extract, $5 \mathrm{~g} \mathrm{~L}^{-1}$ tryptone and $10 \mathrm{~g} \mathrm{~L}^{-1}$ lactose, and transferred into one well of a 12-well plate. The plate was covered with a breathable sealing film and incubated for $48 \mathrm{~h}$ at room temperature on daylight to recover the cells. Finally, the spore suspension was plated in various concentrations onto selective PDA plates containing $100 \mu \mathrm{g} \mathrm{mL} \mathrm{m}^{-1}$ hygromycin $\mathrm{B}$ for antibiotic selection and $0.1 \%$ Triton $\mathrm{X}-100$ as colony restrictor. Colonies appeared after 3 days and were further cultivated separately on PDA plates containing $50 \mu \mathrm{g} \mathrm{mL} \mathrm{m}^{-1}$ hygromycin $\mathrm{B}$ and $50 \mu \mathrm{g} \mathrm{mL} \mathrm{m}^{-1}$ streptomycin ( $\mathrm{PDA}_{\mathrm{hyg} / \text { strep }}$ plates).

Transformants were screened in 300-mL Erlenmeyer flasks in $75 \mathrm{~mL}$ of a modified MA-medium at $30{ }^{\circ} \mathrm{C}$ and $175 \mathrm{rpm}$ for 7 days. The samples were monitored and tested for enzyme activity using the cytochrome $c$ activity assay.

\section{Genomic DNA extraction and colony PCR}

Genomic DNA was extracted from a small amount of mycelium collected from a PDA plate. It was put into a screw-cap microfuge tube together with $0.5-\mathrm{mm}$ glass beads and disrupted using a Precellys 24 homogenizer. Three cycles at $5000 \mathrm{rpm}$ were performed for $60 \mathrm{~s}$ with suspending for $5 \mathrm{~s}$. Subsequently, $150 \mu \mathrm{L}$ of $25 \mathrm{mM}$ Tris$\mathrm{HCl}$ buffer, $\mathrm{pH} 8.0$ containing $50 \mathrm{mM}$ glucose and $10 \mathrm{mM}$ EDTA was added and the tube inverted 5 times. It was centrifuged for $1 \mathrm{~min}$ at $9500 \times \mathrm{g}$ and the supernatant transferred to another tube. For a cleaner sample, the centrifugation was repeated. Five hundred $\mu \mathrm{L}$ of isopropanol was added to the clear supernatant and incubated at $-20^{\circ} \mathrm{C}$ for $2 \mathrm{~h}$. The DNA precipitate was centrifuged at $9500 \times \mathrm{g}$ and $4{ }^{\circ} \mathrm{C}$ for $10 \mathrm{~min}$ and washed with $4{ }^{\circ} \mathrm{C}$-cold $70 \%$ ethanol. The pellet was dried at $60^{\circ} \mathrm{C}$ for $30 \mathrm{~min}$ and re-suspended in $30 \mu \mathrm{L}$ purified $\mathrm{H}_{2} \mathrm{O}$.

ColonyPCR was performed with OneTaq DNA polymerase from NEB according to the manufacturer's manual. As forward primer, the sequencing primer (5pLHseq1, Table 4) that attaches in the promoter region was used. The reverse primer (3PcCDH_colPCR, Table 4) was designed to obtain a 300-bp fragment at the beginning of the gene. The PCR was analyzed by gel electrophoresis using $0.8 \%$ agarose gel, Gel Loading Dye (6X, NEB) and 2-Log DNA Ladder (NEB) in a horizontal Mini-Sub Cell electrophoresis system (Bio-Rad).

\section{Production of $P c C D H$}

Expression of $P c \mathrm{CDH}_{T r}$ in T. reesei was performed in 8 1-L Erlenmeyer flasks in $200 \mathrm{~mL}$ modified MA-medium containing $50 \mu \mathrm{g} \mathrm{mL} \mathrm{m}^{-1}$ streptomycin and $25 \mu \mathrm{g} \mathrm{mL}$ chloramphenicol.

Spores were harvested from 8-days-old $\mathrm{PDA}_{\text {hyg/strep }}$ plates with $\mathrm{NaCl}$-Tween 80 solution $(0.9 \% \mathrm{NaCl}, 0.06 \%$

Table 4 Nucleotide sequences of primers used in this study

\begin{tabular}{ll}
\hline Primer name & Sequence $\left(\mathbf{5}^{\prime}\right.$ to $\left.\mathbf{3}^{\prime}\right)$ \\
\hline $5 \mathrm{pLHseq} 1$ & GCCGGCTTCAAAACACACAG \\
$3 \mathrm{pLHseq1}$ & CAACATAGCATGTCTTATATATTAAGCC \\
3 PcCDH_colPCR & CCTCTCCGATGAACTCAGTGG \\
\hline
\end{tabular}


Tween 80) and each flask was inoculated to a final spore concentration of $1 \times 10^{6} \mathrm{~mL}^{-1}$. The cultures were incubated at $30{ }^{\circ} \mathrm{C}$ and $160 \mathrm{rpm}$. Samples were taken, cleared by centrifugation $\left(13,500 \times g, 10 \mathrm{~min}, 4{ }^{\circ} \mathrm{C}\right)$ and tested for activity using the cytochrome $c$ activity assay.

The production of $P c \mathrm{CDH}$ by $P$. chrysosporium was performed in 1-L Erlenmeyer flasks placed in an orbital shaker at $130 \mathrm{rpm}(2.5 \mathrm{~cm}$ eccentricity) and $30{ }^{\circ} \mathrm{C}$. As inoculum, a $1-\mathrm{cm}^{2}$ slab of a five days old culture on PDA was used and homogenized with an Ultra Turrax blender in $250 \mathrm{~mL}$ of the medium. The supernatant was harvested after eleven days of growth when exhibiting maximum DCIP activity $\left(130 \mathrm{U} \mathrm{L}^{-1}\right)$ and cytochrome $c$ activity $\left(130 \mathrm{U} \mathrm{L}^{-1}\right)$.

\section{Purification of PCCDH}

The shaking flask cultures were harvested by centrifugation $\left(6500 \times g, 30 \mathrm{~min}, 4{ }^{\circ} \mathrm{C}\right)$ and vacuum-filtration through a cellulose-filter. The supernatant of each flask was tested for cytochrome $c$ activity and pooled for further purification.

As first purification step, hydrophobic interaction chromatography was performed. Solid ammonium sulfate was added to the pooled supernatant to reach $25 \%$ saturation and the suspension was cleared from particles by centrifugation $\left(6500 \times g, 30 \mathrm{~min}, 4{ }^{\circ} \mathrm{C}\right)$ and filtration. The sample was loaded to a Phenyl Sepharose FF hydrophobic column ( $250 \mathrm{~mL}$, GE Healthcare) equilibrated with $50 \mathrm{mM}$ sodium acetate buffer, $\mathrm{pH}$ 5.5 containing $25 \%$ (satd.) $\left(\mathrm{NH}_{4}\right)_{2} \mathrm{SO}_{4}$. A linear gradient from 25 to $0 \%\left(\mathrm{NH}_{4}\right)_{2} \mathrm{SO}_{4}$ in $10 \mathrm{mM}$ sodium acetate buffer ( $\mathrm{pH} 5.5$ ) in 4 column volumes was applied and the protein eluted at $5 \%\left(\mathrm{NH}_{4}\right)_{2} \mathrm{SO}_{4}$. Active fractions were pooled, concentrated and dialyzed against $20 \mathrm{mM}$ MES buffer, pH 6.0 containing $25 \mathrm{mM} \mathrm{NaCl}$ using a Vivaflow ${ }^{\circledR} 50$ crossflow module. The sample was applied to a Source $15 \mathrm{Q}$ anion exchange column (19 mL, GE Healthcare) equilibrated with the same buffer. The enzymes were eluted with a linear gradient from 25 to $500 \mathrm{mM} \mathrm{NaCl}$ in 10 column vol-

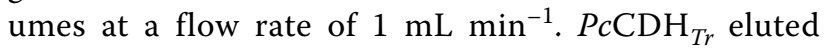
at $135 \mathrm{mM} \mathrm{NaCl}$. Fractions were pooled according to cytochrome $c$ activity and $\mathrm{RZ}\left(\mathrm{A}_{420} / \mathrm{A}_{280}\right)$ value. The enzyme solution was dialyzed against $50 \mathrm{mM}$ sodium acetate buffer, $\mathrm{pH} 5.5$ and concentrated using a Vivaflow ${ }^{\circledR} 50$ crossflow module with a cut-off of $30 \mathrm{kDa}$. The molecular weight of the recombinant protein was determined by SDS-PAGE. PcCDH obtained from $P$. chrysosporium cultures was purified with the same procedure and resulted in an enzyme preparation with an RZ-value of 0.59 .

\section{Electrophoretic analysis}

SDS-PAGE analysis was carried out by using Mini-PROTEAN TGX Stain-Free precast gels (Bio-Rad) according to the manufacturer's instructions. For determination of the molecular mass, the Precision Plus Protein Dual Color Standard marker (Bio-Rad) was used. The deglycosylation of recombinant and native $\mathrm{CDHs}$ was carried out with Endo $\mathrm{H}_{\mathrm{f}}$ from NEB according to their protocol.

\section{MS analysis of glycosylation sites}

The samples were digested in solution. The proteins were S-alkylated with iodoacetamide and digested with Trypsin (Promega, Madison, WI). The digested samples were loaded on a BioBasic C18 column (BioBasic-18, $150 \times 0.32 \mathrm{~mm}, 5 \mu \mathrm{m}$, Thermo Scientific, Waltham, MA) using $80 \mathrm{mM}$ ammonium formate buffer as the aqueous solvent. A gradient from 5\% B (B: $80 \%$ acetonitrile) to $40 \% \mathrm{~B}$ in $45 \mathrm{~min}$ was applied, followed by a $15-\mathrm{min}$ gradient from $40 \%$ B to $90 \%$ B that facilitates elution of large peptides, at a flow rate of $6 \mu \mathrm{L} \mathrm{min}{ }^{-1}$. Detection was performed with QTOF MS (Bruker maXis 4G) equipped with the standard ESI source in positive ion, DDA mode (=switching to MSMS mode for eluting peaks). MS-scans were recorded (range: 150-2200 Da) and the 3 highest peaks were selected for fragmentation. Instrument calibration was performed using ESI calibration mixture (Agilent, Santa Clara, CA). The 6 possible glycopeptides were identified as sets of peaks consisting of the peptide moiety and the attached $\mathrm{N}$-glycan varying in the number of HexNAc units, hexose and phosphate residues. The theoretical masses of these glycopeptides were determined with an EXCEL spread sheet using the monoisotopic masses for amino acids and monosaccharides. Manual glycopeptide searches were made using DataAnalysis 4.0 (Bruker, Billerica, MA). Potential glycosylation sites were determined using the online prediction tool provided by the Department of Bio and Health Informatics from the Technical University of Denmark (http://www.cbs.dtu.dk/services/NetNGlyc).

\section{Spectrophotometry}

The FAD occupancy was determined by the method of trichloroacetic acid (TCA) precipitation. TCA was added to $60 \mu \mathrm{M}$ purified enzyme to a final concentration of $5 \%$. The mixture was heavily mixed for 2 min and cleared by centrifugation $(16,000 \times g, 10 \mathrm{~min})$. The supernatant was adjusted to $\mathrm{pH} 5.5$ by adding grains of $\mathrm{Na}_{2} \mathrm{CO}_{3}$. After another centrifugation step, a spectrum of the supernatant was recorded. The amount of FAD was calculated using the molar absorption coefficient for free FAD $\left(\varepsilon_{450}=11.3 \mathrm{mM}^{-1} \mathrm{~cm}^{-1}\right)$. The $\mathrm{CDH}$ concentration was calculated from the absorbance at $280 \mathrm{~nm}$. The molar 
absorption coefficient of the protein $\left(\varepsilon_{280}=142 \mathrm{mM}^{-}\right.$ ${ }^{1} \mathrm{~cm}^{-1}$ ) was determined by the ProtParam tool (https:// web.expasy.org/protparam) based on the mature amino acid sequence of $P c C D H$. The FAD co-factor also contributes to the absorbance at $280 \mathrm{~nm}$. Therefore, the molar absorption coefficient of free FAD at $280 \mathrm{~nm}$ $\left(\varepsilon_{280}=20.6 \mathrm{mM}^{-1} \mathrm{~cm}^{-1}\right)$ was added proportionally to the FAD loading, resulting in a molar absorption coefficient of $156.4 \mathrm{mM}^{-1} \mathrm{~cm}^{-1}$ for $P c \mathrm{CDH}_{T r}$ (70\% FAD occupancy) and $162.6 \mathrm{mM}^{-1} \mathrm{~cm}^{-1}$ for $P c \mathrm{CDH}$ (100\% FAD occupancy) used for the calculation of the protein concentration.

$\mathrm{UV} /$ Vis spectra were recorded from 250 to $700 \mathrm{~nm}$ with $70 \mu \mathrm{M}$ purified enzyme in $20 \mathrm{mM}$ sodium acetate buffer, $\mathrm{pH}$ 4.0. For measuring the reduced spectrum, $1 \mathrm{mM}$ cellobiose (final concentration) was added to the enzyme solution.

\section{Activity assays and steady-state kinetic measurements}

The catalytic activity in the expression cultures was monitored photometrically by following cytochrome $c$ $\left(\varepsilon_{550}=19.6 \mathrm{mM}^{-1} \mathrm{~cm}^{-1}\right)$ reduction at $550 \mathrm{~nm}$. The assay was performed in $100 \mathrm{mM}$ sodium acetate buffer, $\mathrm{pH}$ 4.5 containing $30 \mathrm{mM}$ lactose as substrate and $20 \mu \mathrm{M}$ cytochrome $c$ as electron acceptor. The reaction was followed for $180 \mathrm{~s}$ at $30^{\circ} \mathrm{C}$.

The $\mathrm{pH}$ profiles were measured in $100 \mathrm{mM}$ Britton-Robinson buffer ( $\mathrm{pH}$ range $2.5-8$ ) containing $500 \mu \mathrm{M}$ cellobiose as substrate. Twenty $\mu \mathrm{M}$ of cytochrome $c, 300 \mu \mathrm{M}$ of 2,6-dichloroindophenol (DCIP, $\left.\varepsilon_{520}=6.9 \mathrm{mM}^{-1} \mathrm{~cm}^{-1}\right)$, or $500 \mu \mathrm{M}$ of 1,4-benzoquinone $\left(\varepsilon_{290}=2.24 \mathrm{mM}^{-1} \mathrm{~cm}^{-1}\right)$ were used as electron acceptors, and the reaction followed at 550, 520, or $290 \mathrm{~nm}$, respectively.

The catalytic constants for cytochrome $c$ were determined in $50 \mathrm{mM}$ sodium acetate buffer, $\mathrm{pH} 4.0$ with $500 \mu \mathrm{M}$ cellobiose as saturating substrate and a cytochrome $c$ concentration ranging from 0.125 to $20 \mu \mathrm{M}$. Catalytic constants for DCIP were measured in $50 \mathrm{mM}$ sodium acetate buffer, $\mathrm{pH} 4.5$ with $500 \mu \mathrm{M}$ cellobiose as saturating substrate and a DCIP concentration between 0.5 and $100 \mu \mathrm{M}$. The determination of the catalytic constants for electron donors was performed with $300 \mu \mathrm{M}$ DCIP in $50 \mathrm{mM}$ sodium acetate buffer, $\mathrm{pH}$ 4.5. The cellobiose concentration was varied between 10 and $800 \mu \mathrm{M}$, lactose was measured between 0.25 and $80 \mathrm{mM}$ and for glucose a range from 0.1 to $2.6 \mathrm{M}$ was used. Catalytic constants were calculated by fitting the measured data to the Michaelis-Menten equation using a non-linear least squares regression in SigmaPlot 12.0 (Systat Software). All measurements were performed in triplicates.

The determination of the reaction rates of monoand di-substituted 1,4-benzoquinones was performed in $50 \mathrm{mM}$ sodium acetate buffer, $\mathrm{pH} 4.0$ with $0.5 \mathrm{mM}$ cellobiose as substrate and $50 \mu \mathrm{M}$ of the respective quinone (2,5-dimethoxy-1,4-benzoquinone was measured with $38 \mu \mathrm{M}$ due to solubility reasons). Five $\mathrm{mM}$ stock solutions of 1,4-benzoquinone, methyl-1,4-benzoquinone and methoxy-1,4-benzoquinone were prepared in water. 2,6-Dimethyl-1,4-benzoquinone and 2,6-dimethoxy-1,4-benzoquinone were prepared as $5 \mathrm{mM}$ stock solutions in DMSO, 2,5-dimethoxy-benzoquinone as $1 \mathrm{mM}$ stock solution in DMSO. Their reaction was followed using their respective molar absorption coefficients: $\varepsilon_{246}=20.30 \mathrm{mM}^{-1} \mathrm{~cm}^{-1}$, $\varepsilon_{251}=21.45 \mathrm{mM}^{-1} \mathrm{~cm}^{-1}, \quad \varepsilon_{256}=15.29 \mathrm{mM}^{-1} \mathrm{~cm}^{-1}$, $\varepsilon_{257}=18.04 \mathrm{mM}^{-1} \mathrm{~cm}^{-1}, \varepsilon_{292}=13.68 \mathrm{mM}^{-1} \mathrm{~cm}^{-1}$, and $\varepsilon_{281}=25.96 \mathrm{mM}^{-1} \mathrm{~cm}^{-1} \mathrm{~nm}$.

\section{Redox potential of $P C C D H_{T r}$}

Preparation of $\mathrm{CDH}$-thiol-modified gold electrodes $(\varnothing$ $3 \mathrm{~mm}$, BAS Inc,) started with mechanical cleaning of the electrode by polishing in an aqueous alumina suspension (Masterprep $0.05 \mu \mathrm{m}$, Buehler, DE), rinsed with purified $\mathrm{H}_{2} \mathrm{O}$ and sonicated in purified $\mathrm{H}_{2} \mathrm{O}$ for $10 \mathrm{~min}$ to remove residual alumina particles. The electrodes were then subjected to electrochemical cleaning in $0.5 \mathrm{M} \mathrm{H}_{2} \mathrm{SO}_{4}$ for 20 cycles with a scan rate of $200 \mathrm{mV} \mathrm{s}^{-1}$, between -250 and $1700 \mathrm{mV}$ versus $\mathrm{Ag} /$ $\mathrm{AgCl}$ using cyclic voltammetry, and finally rinsed with purified $\mathrm{H}_{2} \mathrm{O}$. Thiol pretreatment of the gold electrodes was achieved by immersion in $15 \mathrm{mM}$ 1-thioglycerol in 96\% ethanol for 90 min to form a self-assembled monolayer (SAM) on the gold surface. Then, $2 \mu \mathrm{L}$ of enzyme ( $5 \mathrm{mg} \mathrm{mL}^{-1}$ ) solution was smeared onto the thiol-modified electrodes. The entrapment of enzyme was achieved by covering the electrode with a dialysis membrane (cut-off 6000-8000 Da) which is fitted tightly to the electrode with a rubber O-ring. The assembly was then sealed with parafilm, leaving out the electrode surface. The electrochemical measurements were performed using an Autolab PGSTAT204 potentiostat (Metrohm). Modified gold electrode, platinum wire, and $\mathrm{Ag} / \mathrm{AgCl}$ were used as the working-, counter-, and reference $\left(+205 \mathrm{mV}\right.$ vs. NHE at $\left.25{ }^{\circ} \mathrm{C}\right)$ electrodes, respectively. All measurements were performed at room temperature in $100 \mathrm{mM}$ potassium-phosphate buffer, $\mathrm{pH} 6.0$ containing $100 \mathrm{mM}$ potassium chloride. The electrolytes of different $\mathrm{pH}$ values for midpoint potential measurements were prepared by titration of $1 \mathrm{M} \mathrm{NaOH}$ into a universal buffer solution of the following composition: $10 \mathrm{mM}$ acetate, $10 \mathrm{mM}$ phosphate, and $100 \mathrm{mM} \mathrm{KCl}$. The electrolyte was always purged with nitrogen for 15 min prior to the experiment, and a stream of nitrogen was maintained during the measurement. 


\section{Supplementary Information}

The online version contains supplementary material available at https://doi. org/10.1186/s12934-020-01492-0.

Additional file 1:Vector map of plasmid pLH_hph_nat containing the gene sequence of $P C C D H$ under control of the CDNA1 promoter, the hygromycin $B$ and ampicillin resistance gene cassettes, ORI for replication in E. coli and a Sbfl restriction site for linearization. Figure S2. PCCDH amino acid sequence (755 amino acids) with six potential $\mathrm{N}$-glycosylation sites highlighted in blue (as predicted by http://www.cbs.dtu.dk/services/ NetNGlyc). Positions verified by mass spectrometry are underlined. Figure S3. Tryptic digest of $P_{C} C D H_{T r}$ and $P C C D H$ covering the $\mathrm{N}$-glycosylation sequon at position N111. Figure S4. Tryptic digest of $P_{C} C D H_{T r}$ and $P C C D H$ covering the $\mathrm{N}$-glycosylation sequon at position N419. Figure S5. Tryptic digest of $P_{C} C D H_{T r}$ and $P C C D H$ covering the $\mathrm{N}$-glycosylation sequon at position N434. Figure S6. Tryptic digest of $P_{C} C D H_{T r}$ and $P C C D H$ covering the N-glycosylation sequon at position N553. Figure S7. Tryptic digest of $\mathrm{PCCDH}_{T_{r}}$ covering the $\mathrm{N}$-glycosylation sequon at position N593 and N599.

\section{Acknowledgements}

We gratefully thank Dr. Clemens Grünwald-Gruber for MS analysis of PCCDH samples.

\section{Authors' contributions}

LW and RL planned the study, LW and EF performed cloning and transformation experiments, LW and FC produced and purified enzymes, LW performed the biochemical characterization, $\mathrm{HC}$ ran electrochemical experiments, LW and RL analyzed and interpreted data, LW wrote the first draft of the manuscript, BS and RL prepared the submitted manuscript. All authors read and approved the final manuscript.

\section{Funding}

This project has received funding from the European Union's Horizon 2020 research and innovation programme (ERC Consolidator Grant OXIDISE) under Grant Agreement No 726396.

\section{Availability of data and materials}

All data generated or analyzed during this study are included in this published article and its additional file.

\section{Ethics approval and consent to participate}

Not applicable.

\section{Consent for publication}

Not applicable.

\section{Competing interests}

The authors declare that they have no competing interests.

\section{Author details}

${ }^{1}$ Biocatalysis and Biosensing Laboratory, Department of Food Science and Technology, BOKU-University of Natural Resources and Life Sciences, Muthgasse 18, 1190 Vienna, Austria. ${ }^{2}$ Research Division Biochemical Technology, Institute of Chemical, Environmental and Bioscience Engineering, TU Wien, 1060 Vienna, Austria.

Received: 22 September 2020 Accepted: 3 December 2020 Published online: 06 January 2021

\section{References}

1. Henrich E, Dahmen N, Dinjus E, Sauer J. The role of biomass in a future world without fossil fuels. Chem Ing Tech. 2015;87:1667-85.

2. Dashtban M, Schraft H, Syed TA, Qin W. Fungal biodegradation and enzymatic modification of lignin. Int J Biochem Mol Biol. 2010;1:36-50.

3. Martínez ÁT, Speranza M, Ruiz-Dueñas FJ, Ferreira P, Camarero S, Guillén F, Martínez MJ, Gutiérrez A, Del Río JC. Biodegradation of lignocellulosics: microbial, chemical, and enzymatic aspects of the fungal attack of lignin. Int Microbiol. 2005;8:195-204.

4. Zamocky M, Ludwig R, Peterbauer C, Hallberg B, Divne C, Nicholls $P$, Haltrich D. Cellobiose dehydrogenase-a flavocytochrome from wood-degrading, phytopathogenic and saprotropic fungi. Curr Protein Pept Sci. 2006;7:255-80.

5. Westermark U, Eriksson K-E. Cellobiose: Quinone oxidoreductase, a new wood-degrading enzyme from white-rot fungi. Acta Chem Scand. 1974;28b:209-14.

6. Bao WJ, Usha SN, Renganathan V. Purification and characterization of cellobiose dehydrogenase, a novel extracellular hemoflavoenzyme from the white-rot fungus Phanerochaete chrysosporium. Arch Biochem Biophys. 1993;300:705-13.

7. Sygmund C, Kracher D, Scheiblbrandner S, Zahma K, Felice AKG, Harreither W, Kittl R, Ludwig R. Characterization of the two Neurospora crassa cellobiose dehydrogenases and their connection to oxidative cellulose degradation. Appl Environ Microbiol. 2012;78:6161-71.

8. Henriksson G, Zhang L, Li J, Ljungquist P, Reitberger T, Pettersson $\mathrm{G}$, Johansson $\mathrm{G}$. Is cellobiose oxidase from Phanerochaete chrysosporium a lignin degrading enzyme? Biochim Biophys Acta Bioenerg. 2000;1480:83-91.

9. Kracher D, Ludwig R. Cellobiose dehydrogenase: an essential enzyme for lignocellulose degradation in nature-a review. Bodenkultur. 2016:67:145-63.

10. Vaaje-Kolstad G, Westereng B, Horn SJ, Liu Z, Zhai H, Sørlie M, Eijsink VGH. An oxidative enzyme boosting the enzymatic conversion of recalcitrant polysaccharides. Science. 2010;330:219-22.

11. Kracher D, Forsberg Z, Bissaro B, Gangl S, Preims M, Sygmund C, Eijsink VGH, Ludwig R. Polysaccharide oxidation by lytic polysaccharide monooxygenase is enhanced by engineered cellobiose dehydrogenase. FEBS J. 2020;287:897-908.

12. Bissaro B, Røhr ÅK, Müller G, Chylenski P, Skaugen M, Forsberg Z, Horn SJ, Vaaje-Kolstad G, Eijsink VGH. Oxidative cleavage of polysaccharides by monocopper enzymes depends on $\mathrm{H}_{2} \mathrm{O}_{2}$. Nat Chem Biol. 2017;13:1123-8.

13. Scheiblbrandner S, Ludwig R. Cellobiose dehydrogenase: Bioelectrochemical insights and applications. Bioelectrochemistry. 2019;131:107345.

14. Igarashi K, Verhagen MFJM, Samejima M, Schulein M, Eriksson KL, Nishino T. Cellobiose dehydrogenase from the fungi Phanerochaete chrysosporium and Humicola insolens. J Biol Chem. 1999;274:3338-44.

15. Henriksson G, Sild V Szabó IJ, Pettersson G, Johansson G. Substrate specificity of cellobiose dehydrogenase from Phanerochaete chrysosporium. Biochim Biophys Acta Protein Struct Mol Enzymol. 1998;1383:48-54

16. Li B, Rotsaert FAJ, Gold MH, Renganathan V. Homologous expression of recombinant cellobiose dehydrogenase in Phanerochaete chrysosporium. Biochem Biophys Res Commun. 2000;270:141-6.

17. Yoshida M, Ohira T, Igarashi K, Nagasawa H, Aida K, Hallberg BM, Divne C, Nishino T, Samejima M. Production and characterization of recombinant Phanerochaete chrysosporium cellobiose dehydrogenase in the methylotrophic yeast Pichia pastoris. Biosci Biotechnol Biochem. 2001;65:2050-7.

18. Laukens B, De Wachter C, Callewaert N. Engineering the Pichia pastoris $\mathrm{N}$-glycosylation pathway using the GlycoSwitch technology BT. In: Castilho A, editor. Glyco-engineering methods mol. New York: Humana Press; 2015. p. 103-22.

19. Desriani S, Ferri K. Sode, Functional expression of Phanerochaete chrysosporium cellobiose dehydrogenase flavin domain in Escherichia coli. Biotechnol Lett. 2010;32:855-9.

20. Ma S, Preims M, Piumi F, Kappel L, Seiboth B, Record E, Kracher D, Ludwig R. Molecular and catalytic properties of fungal extracellular cellobiose dehydrogenase produced in prokaryotic and eukaryotic expression systems. Microb Cell Fact. 2017;16:1-14.

21. Druzhinina IS, Kubicek CP. Genetic engineering of Trichoderma reesei cellulases and their production. Microb Biotechnol. 2017;10:1485-99.

22. Wang M, Lu X. Exploring the synergy between cellobiose dehydrogenase from Phanerochaete chrysosporium and cellulase from Trichoderma reesei. Front Microbiol. 2016;7:1-10.

23. Uzbas F, Sezerman U, Hartl L, Kubicek CP, Seiboth B. A homologous production system for Trichoderma reesei secreted proteins in a cellulase-free background. Appl Microbiol Biotechnol. 2012;93:1601-8. 
24. Stricker AR, Grosstessner-Hain K, Würleitner E, Mach RL. Xyr1 (Xylanase Regulator 1) regulates both the hydrolytic enzyme system and D-xylose metabolism in Hypocrea jecorina. Eukaryot Cell. 2006;5:2128-37.

25. Schuster A, Bruno KS, Collett JR, Baker SE, Seiboth B, Kubicek CP, Schmoll $M$. A versatile toolkit for high throughput functional genomics with Trichoderma reesei. Biotechnol Biofuels. 2012;5:1-10.

26. Kück U, Hoff B. New tools for the genetic manipulation of filamentous fungi. Appl Microbiol Biotechnol. 2010;86:51-62.

27. Guangtao Z, Hartl L, Schuster A, Polak S, Schmoll M, Wang T, Seidl V, Seiboth B. Gene targeting in a nonhomologous end joining deficient Hypocrea jecorina. J Biotechnol. 2009;139:146-51.

28. Desriani S, Ferri K. Sode, Amino acid substitution at the substrate-binding subsite alters the specificity of the Phanerochaete chrysosporium cellobiose dehydrogenase. Biochem Biophys Res Commun. 2010;391:1246-50.

29. Cereghino JL, Cregg JM. Heterologous protein expression in the methylotrophic yeast Pichia pastoris. FEMS Microbiol Rev. 2000;24:45-66.

30. Hui JPM, White TC, Thibault P. Identification of glycan structure and glycosylation sites in cellobiohydrolase II and endoglucanases I and II from Trichoderma reesei. Glycobiology. 2002;12:837-49.

31. Hui JPM, Lanthier P, White TC, McHugh SG, Yaguchi M, Roy R, Thibault P. Characterization of cellobiohydrolase I (Cel7A) glycoforms from extracts of Trichoderma reesei using capillary isoelectric focusing and electrospray mass spectrometry. J Chromatogr B Biomed Sci Appl. 2001;752:349-68.

32. Klarskov K, Piens K, Ståhlberg J, Høj PB, Van Beeumen J, Claeyssens M. Cellobiohydrolase I from Trichoderma reesei: Identification of an active-site nucleophile and additional information on sequence including the glycosylation pattern of the core protein. Carbohydr Res. 1997;304:143-54.

33. Stals I, Sandra K, Geysens S, Contreras R, Van Beeumen J, Claeyssens M. Factors influencing glycosylation of Trichoderma reesei cellulases. I: Postsecretorial changes of the $\mathrm{O}$ - and $\mathrm{N}$-glycosylation pattern of $\mathrm{Ce} 17 \mathrm{~A}$. Glycobiology. 2004;14:713-24

34. Stals I, Samyn B, Sergeant K, White T, Hoorelbeke K, Coorevits A, Devreese B, Claeyssens M, Piens K. Identification of a gene coding for a deglycosylating enzyme in Hypocrea jecorina. FEMS Microbiol Lett. 2010;303:9-17.
35. Žoldák G, Šut'ák R, Antalík M, Sprinzl M, Sedlák E. Role of conformational flexibility for enzymatic activity in NADH oxidase from Thermus thermophilus. Eur J Biochem. 2004;270:4887-97.

36. Harreither W, Felice AKG, Paukner R, Gorton L, Ludwig R, Sygmund C. Recombinantly produced cellobiose dehydrogenase from Corynascus thermophilus for glucose biosensors and biofuel cells. Biotechnol J. 2012;7:1359-66.

37. Rotsaert FAJ, Li B, Renganathan V, Gold MH. Site-directed mutagenesis of the heme axial ligands in the hemoflavoenzyme cellobiose dehydrogenase. Arch Biochem Biophys. 2001;390:206-14.

38. Kracher D, Scheiblbrandner S, Felice AKG, Breslmayr E, Preims M, Ludwicka K, Haltrich D, Eijsink VGH, Ludwig R. Extracellular electron transfer systems fuel cellulose oxidative degradation. Science. 2016;352:1098-101.

39. El-Najjar N, Gali-Muhtasib H, Ketola RA, Vuorela P, Urtti A, Vuorela H. The chemical and biological activities of quinones: Overview and implications in analytical detection. Phytochem Rev. 2011;10:353-70.

40. Igarashi K, Momohara I, Nishino T, Samejima M. Kinetics of inter-domain electron transfer in flavocytochrome cellobiose dehydrogenase from the white-rot fungus Phanerochaete chrysosporium. Biochem J. 2002:365:521-6.

41. Igarashi K, Yoshida M, Matsumura H, Nakamura N, Ohno H, Samejima M, Nishino T. Electron transfer chain reaction of the extracellular flavocytochrome cellobiose dehydrogenase from the basidiomycete Phanerochaete chrysosporium. FEBS J. 2005;272:2869-77.

42. Li B, Nagalla SR, Renganathan V. Cloning of a cDNA encoding cellobiose dehydrogenase, a hemoflavoenzyme from Phanerochaete chrysosporium. Appl Environ Microbiol. 1996:62:1329-35.

\section{Publisher's Note}

Springer Nature remains neutral with regard to jurisdictional claims in published maps and institutional affiliations.
Ready to submit your research? Choose BMC and benefit from:

- fast, convenient online submission

- thorough peer review by experienced researchers in your field

- rapid publication on acceptance

- support for research data, including large and complex data types

- gold Open Access which fosters wider collaboration and increased citations

- maximum visibility for your research: over 100M website views per year

At BMC, research is always in progress.

Learn more biomedcentral.com/submissions 